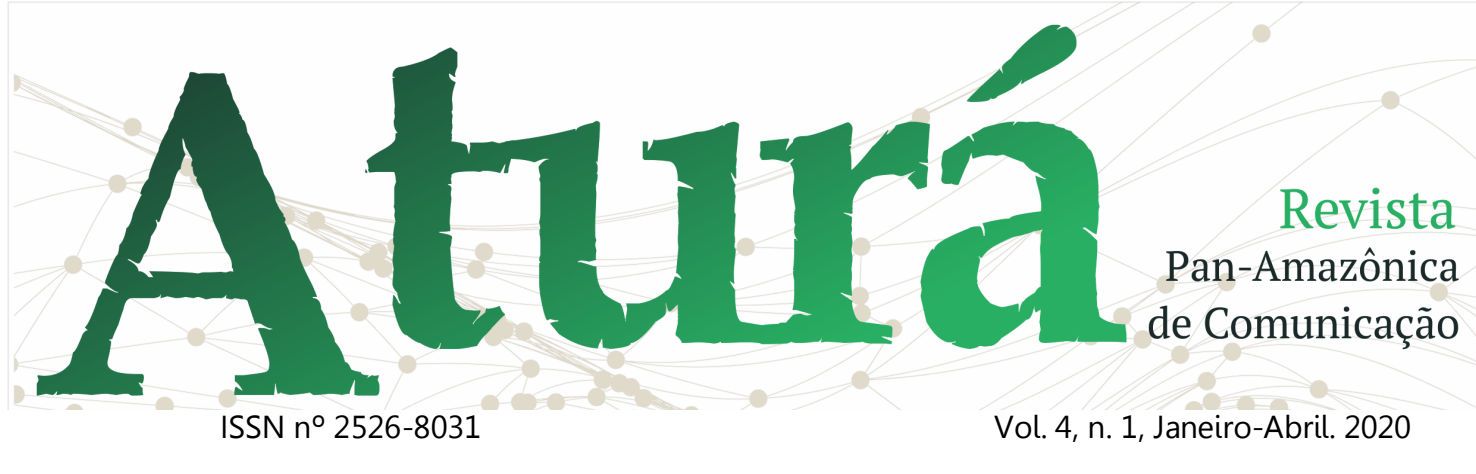

DOI: http://dx.doi.org/10.20873/uft.2526-8031.2020v4n1p80

\title{
QUANDO O JORNAL SE TORNA MULTIPLATAFORMA: análise das capas de O Liberal no impresso e no digital
}

When the newspaper becomes multiplatform: analysis of the print and digital covers of O Liberal

Cuando el periódico se convierte em multiplataforma: análisis de las portadas impresas y digitales del periódico O Liberal

\section{Giovanna Figueiredo de $\mathrm{Abreu}^{1}$ Maíra Evangelista de Sousa ${ }^{2,3}$}

\section{RESUMO}

Este artigo tem o objetivo de analisar as características pertinentes à capa do jornal O Liberal no impresso e no digital, com foco na apresentação visual. A pesquisa de caráter exploratório combinou as seguintes técnicas qualitativas: pesquisa bibliográfica, coleta de dados e análise. A análise foi realizada tendo como base a edição do dia três de julho de 2019 dos jornais impresso e digital, com base nas seguintes categorias: nome do jornal, diagramação, editorias, manchetes, disposição das notícias, imagens estáticas e em movimento, cores, tipografia, links e publicidade. Concluiu-se que há um diálogo entre os dois produtos, embora eles demonstrem independência na apresentação visual.

PALAVRAS-CHAVE: Jornalismo impresso; Jornalismo Digital; Multiplataforma; Capas; O Liberal.

\footnotetext{
1 Mestranda do Programa de Pós-Graduação em Comunicação, Linguagens e Cultura (PPGCLC) da Universidade da Amazônia (UNAMA). Graduada em Jornalismo pela Universidade da Amazônia (UNAMA). É membro dos Grupos de Pesquisa "Ubiquidade na Comunicação" (UBICOM/UNAMA) e "Interações e Tecnologias na Amazônia - ITA" (UFPA/UNAMA/CNPq). E-mail: giovannamfigueiredo@gmail.com.

2. Pós-doutoranda do Programa de Pós-Graduação Comunicação, Cultura e Amazônia da Universidade Federal do Pará. Doutora em Comunicação e Informação pela Universidade Federal do Rio Grande do Sul. Professora do Programa de Pós-Graduação em Comunicação, Linguagens e Cultura (PPGCLC) e dos cursos de Jornalismo e de Publicidade e Propaganda da Universidade da Amazônia. Coordenadora do Grupo de Pesquisa "Ubiquidade na Comunicação" (UBICOM / UNAMA). E-mail: maira.evangelistadesousa@gmail.com.

${ }^{3}$ Endereço de contato com os autores (por correio): Universidade da Amazônia (UNAMA). Av. Alcindo Cacela, 287 Umarizal, Belém-Pará, Brasil. CEP 66065-205.
} 


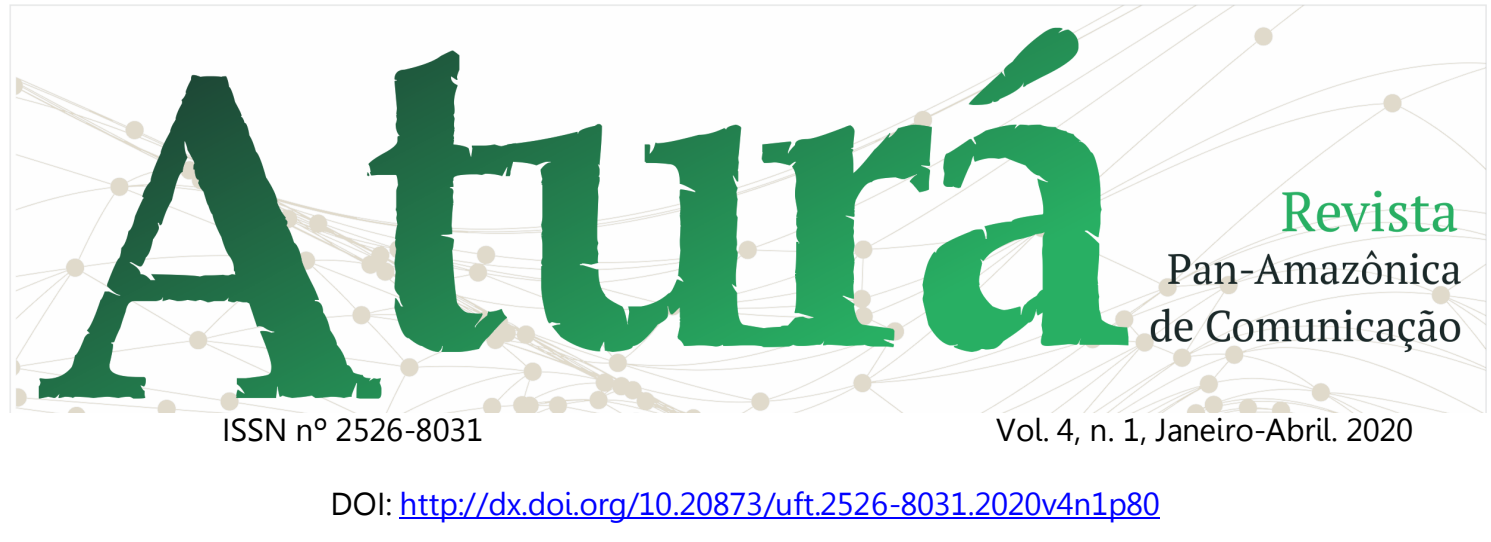

\begin{abstract}
This article aims to analyze the main characteristics related to the cover of the newspaper $O$ Liberal in its print and digital versions, focusing on visual presentation. The exploratory research combined the following qualitative techniques: bibliographic research, data collection and analysis. The analysis was conducted based on the print and digital edition of the newspaper in July 3, 2019, regarding the following categories: newspaper name, layout, editorials, headlines, news layout, still and moving images, colors, typography, links and advertising. It was concluded that there is a dialogue between the two products, although they demonstrate independence in the visual presentation.
\end{abstract}

KEYWORDS: Printed journalism; Digital journalism; Multiplataform; Covers; O Liberal.

\title{
RESUMEN
}

Este artículo tiene como objetivo analizar las características relacionadas a la portada del periódico O Liberal en forma impresa y digital, con un enfoque en la presentación visual. La investigación exploratoria combinó las siguientes técnicas cualitativas: investigación bibliográfica, recopilación y análisis de datos. El análisis se realizó basada en la edición del 3 de julio de 2019 de los periódicos impresos y digitales, basados en las siguientes categorías: nombre del periódico, diagramación, editoriales, titulares, diseño de noticias, imágenes fijas y en movimiento, colores, tipografía, enlaces y publicidad. Se concluyó que existe un diálogo entre los dos productos, aunque demuestren independencia en la presentación visual.

PALABRAS CLAVE: Periodismo impreso; Periodismo digital; Multiplataforma; Portadas; O Liberal..

Recebido em: 12.11.2019. Aceito em: 12.12.2019. Publicado em: 03.01.2020. 


\section{A \\ ISSN n 2526-8031 \\ Vol. 4, n. 1, Janeiro-Abril. 2020 \\ Revista \\ Pan-Amazônica \\ de Comunicação \\ DOI: http://dx.doi.org/10.20873/uft.2526-8031.2020v4n1p80}

\section{Introdução}

O jornal é um produto editorial que se reconfigura de acordo com as transformações sociais, culturais e tecnológicas. Ele é identificado por uma marca - nome do jornal (MOUILLAUD, 1997) - de valor ideológico e econômico (GRUSZYNSKI, 2016). Nos dias atuais, o jornal existente é aquele que resistiu (PARK, 2008) às reconfigurações da sociedade e, consequentemente, do jornalismo.

Em um cenário de convergência jornalística (KOLODZY, 2006, 2009; SALAVERRÍA; AVILÉS; MASIP, 2010), OS tradicionais veículos que construíram sua identidade e credibilidade associada à publicação em papel, se adaptam e investem em outros produtos para conquistar novos públicos e manter o antigo, simultaneamente. Assim, o jornal torna-se um produto multiplataforma (SOUSA, 2018; SOUSA, 2017).

Nesse sentido, com base em Gruszynski e Sanseverino (2017), Sousa
(2018) compreende que a publicação multiplataforma refere-se à distribuição de conteúdo editorial, por parte das organizações jornalísticas, em distintas plataformas. De maneira que:

Há uma ampliação dos produtos jornalísticos que ganham novas conformações e passam a circular em fluxo, envolvendo além do papel, computadores de mesa, notebooks, celulares, kindles, smartphones, tablets, relógios inteligentes, dentre outros. Esse conteúdo passa a ser produzido de forma integrada, de modo que as potencialidades de cada um dos suportes e das plataformas sejam consideradas. As marcas de reconhecimento do jornal são levadas para esses novos produtos ampliando também os vínculos estabelecidos com os leitores. Com isso, o público pode ter acesso às informações jornalísticas de forma contínua, em qualquer lugar e momento, ao mesmo tempo que contribuem para a potencialização do fluxo de informações por meio de ações participativas que aumentam a propagação desses conteúdos. (SOUSA, 2018, p. 15-16).

Diante desse cenário, este artigo tem o objetivo de analisar as características pertinentes à capa do jornal impresso $O$ Liberal e do portal OLiberal.com ${ }^{4}$, com foco na apresentação visual. Os dois produtos em análise

\footnotetext{
${ }^{4}$ Disponível em: <https://www.oliberal.com/>. Acesso em: 28 set. 2019.
} 


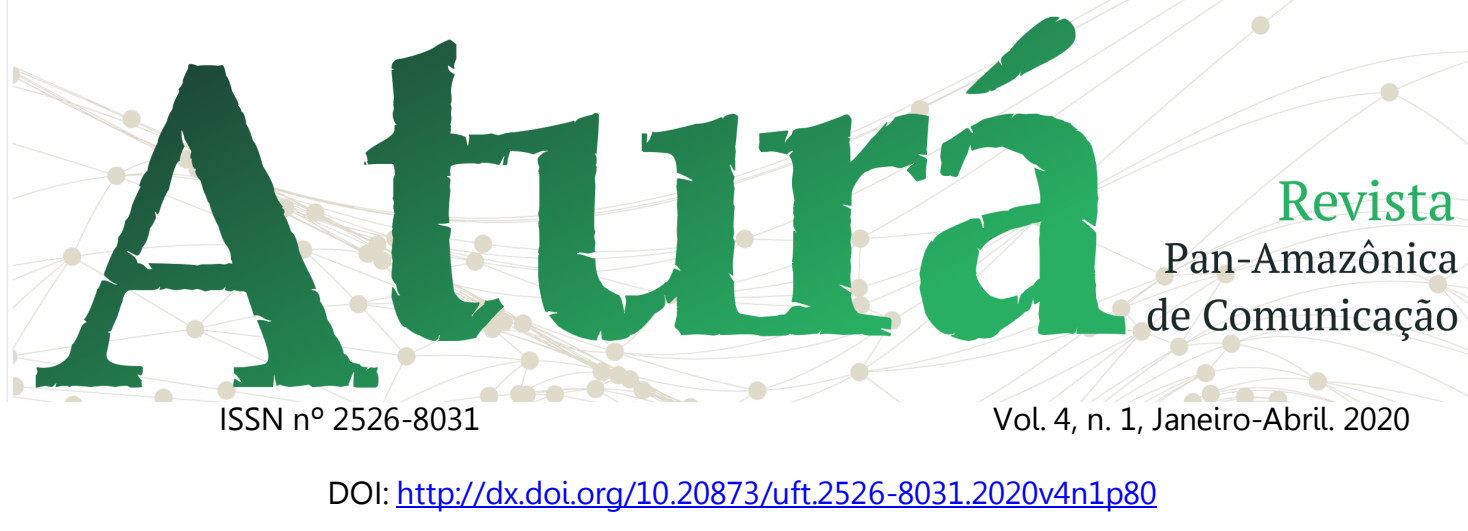

pertencem ao Grupo Liberal. Sediado em Belém, é o maior grupo de comunicação do estado do Pará. O jornal impresso $O$ Liberal foi criado em 1966 e é considerado o diário mais antigo em circulação no estado do Pará (CASTRO; SEIXAS, 2013). Ele também foi o primeiro jornal paraense a disponibilizar conteúdo jornalístico nas plataformas digitais, a partir de 1997, por meio do site $O$ Liberal Online, que em 2004 se transformou em Portal ORM (SOUSA, 2008) e em 2018, em OLiberal.com (SOUSA; ABREU, 2019)

Este estudo é constituído por uma pesquisa exploratória, a qual combina técnicas qualitativas (pesquisa bibliográfica, coleta de dados e análise), baseada em Richardson (1999) e Gil (1999), aplicadas às capas do jornal impresso e do jornal digital do grupo $O$ Liberal. A análise foi realizada a partir de dez categorias principais: nome do jornal, diagramação, editorias, manchetes, disposição das notícias, imagens estáticas e em movimento, cores, tipografia, links e publicidade.
O artigo está dividido em duas partes principais. $\mathrm{Na}$ primeira, apresentamos conceitos referentes às capas dos jornais no impresso e no digital. Já na segunda, realizamos a análise do nosso objeto empírico. Dentre as conclusões, verificamos que há um diálogo entre os dois produtos, apesar da independência na apresentação visual de cada um.

\section{Capas de jornais: impresso e digital}

O jornal, invenção social e cultural, assume diferentes conformações na sua relação com as especificidades da atividade jornalística e com as dinâmicas mais amplas da sociedade. A editoração dos jornais impressos e a publicação de informações em suportes digitais só foi possível graças à popularização de computadores e da internet, recursos que começaram a ser desenvolvidos ainda no início da segunda metade do século XX. A partir dos anos 1980, as redações do jornal impresso foram informatizadas e, devido a esse processo, o fazer jornalístico passa por profundas modificações. Nos anos 


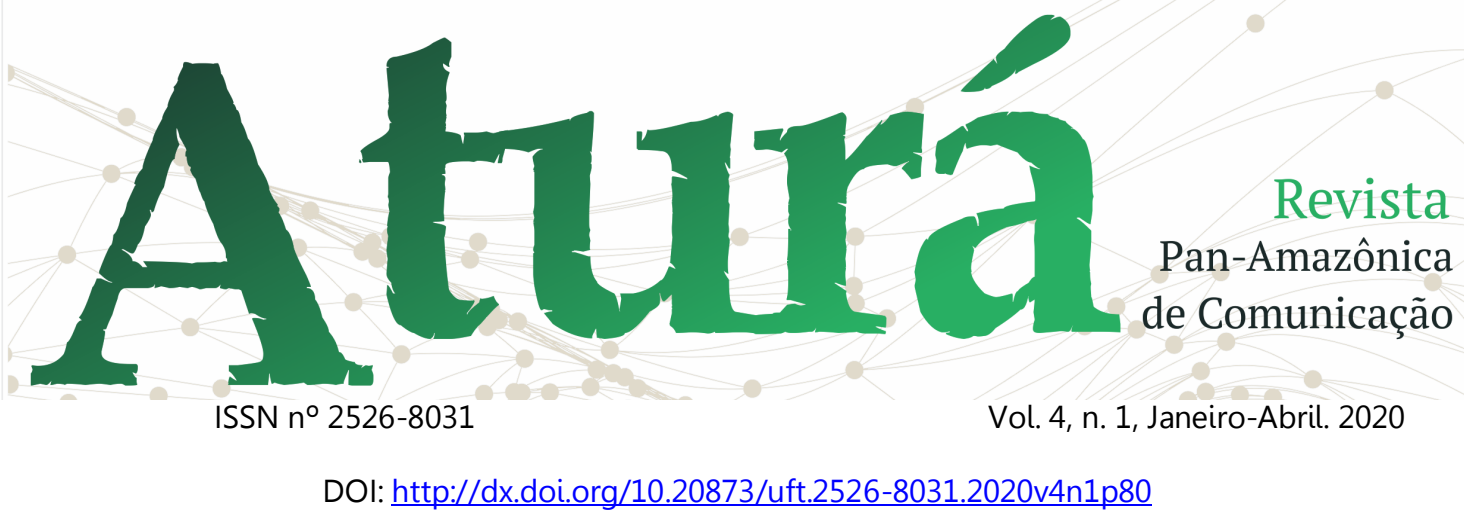

1990, com a chegada da internet, ocorrem novas mudanças nas redações e surge um novo espaço para a publicação de conteúdos noticiosos: os sites que mais tarde dão lugar aos portais (SOUSA, 2018).

As características do jornalismo digital - $\quad$ hipertextualidade, multimidialidade, interatividade, instantaneidade, personalização, memória e ubiquidade (CANAVILHAS, 2014) tornaram $\bigcirc$ ambiente propício para mudanças. Assim, alteraram-se as noções de tempo e espaço, a intensidade de troca de dados, o alcance e as potencialidades das informações jornalísticas na rede.

Nesse sentido, à medida que a sociedade se transforma, se alteram as configurações dos jornais. Park (2008, p. 33) entende que "O tipo de jornal que existe é o tipo que sobreviveu sob as condições da vida moderna." Em perspectiva similar, Gruszynski (2016, p. 183) afirma que "[...] o que é denominado contemporaneamente como jornal assume contornos variados nas plataformas em que está disponível." Para a autora, as mudanças na apresentação visual do jornal estão relacionadas à união de processos, práticas editoriais e tecnologias produtivas, tendo em vista que este é herdeiro da cultura do livro e foi um dos pioneiros - dentre os produtos editoriais - a ingressar nos suportes digitais (GRUSZYNSKI, 2010). Mouillaud (1997, p. 25), por sua vez, explica que "Um quadro (a diagramação) foi progressivamente constituído ao longo da história do jornal: paginação - disposição em colunas - seções - títulos".

Um conjunto de marcas fizeram da página do jornal diário não apenas um texto, mas uma 'área espacial'. Assim, o jornal configura-se como "uma forma estruturada de comunicação, um dispositivo que compreende um conjunto sistemático e articulado de elementos verbais e visuais que conforma conteúdos diversos em uma trama que contribui para lhes conferir sentidos potenciais." (BANDEIRA et al., 2016, p. 93). Além dessas modalidades, as edições multiplataforma podem compreender também recursos sonoros e táteis. 


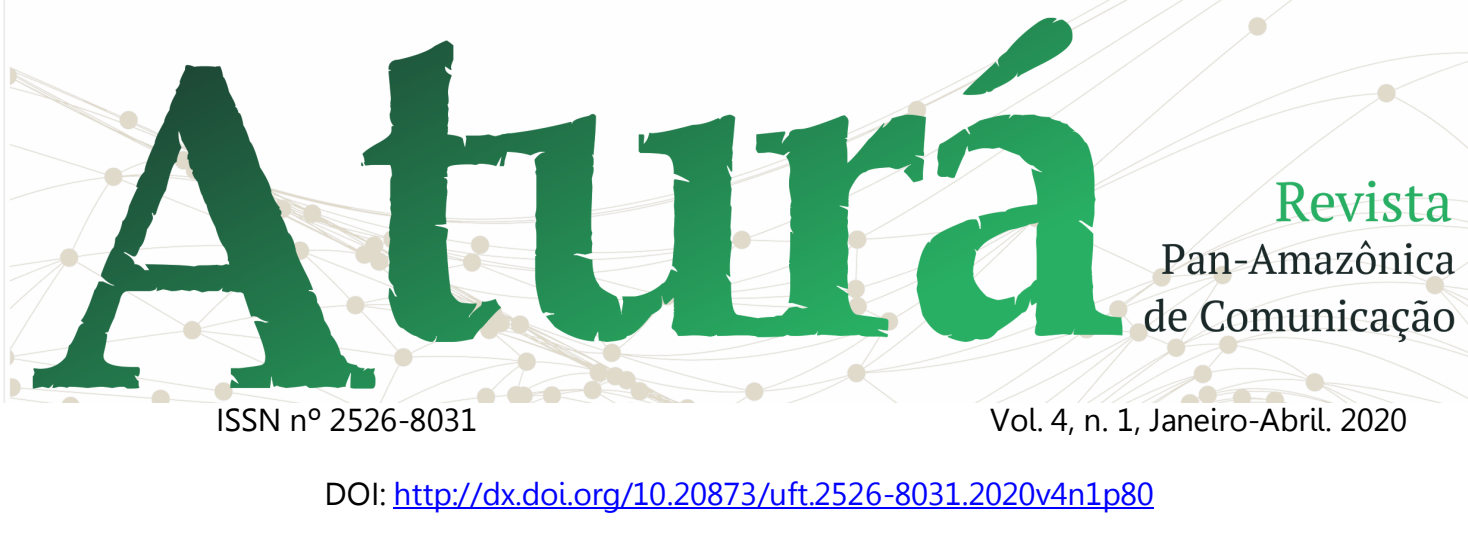

Na medida em que os jornais são disponibilizados em plataformas digitais, os vínculos estabelecidos historicamente entre jornais impressos e público, que são operacionalizados por contratos de comunicação (CHARAUDEAU, 2007), se deslocam para esses ambientes (GRUSZYNSKI, 2012). Há, portanto, uma ampliação, uma alteração e um redimensionamento desses contratos, que passam a ter especificidades em relação a cada uma das plataformas utilizadas (BELOCHIO, 2012; GRUSZYNSKI; LINDEMANN; OLIVEIRA, 2014; SILVA, 2018; SEIXAS, 2018).

O reconhecimento de um jornal se dá pelo projeto gráfico, uma vez que ele "dá maior visibilidade à identidade dos títulos, assegurando o lugar do nome do jornal como o enunciado primeiro que dá credibilidade ao conjunto de informações veiculadas em cada número" (GRUSZYNSKI, 2012, p. 91). Nesse sentido, segundo a autora, o nome do jornal representa a identidade e a credibilidade do veículo jornalístico nas mais diversas plataformas. O projeto gráfico tem como principais elementos $\circ$ formato (especificações do suporte) e o espaço gráfico (organizado conforme um diagrama - grid, onde são colocados textos, imagens e recursos de apoio como fios e texturas com cor característica) (GRUSZYNSKI, 2012).

No papel, características referentes à materialidade como espessura, peso, modo de encadernação, tamanho e textura, permitem que o leitor identifique qual é o tipo de publicação (GRUSZYNSKI, 2012), possibilitando a associação com uma classe de textos e de usos particulares (CHARTIER, 2002). No que se refere ao suporte, a publicação em papel tem a vantagem de não precisar de nenhum aparelho técnico para ser lida, sendo "imediatamente visível, folheável e consultável e de ser fácil de emprestar." (FURTADO， 2006, p. 90). Uma apresentação visual clara e legível favorece que as informações sejam compreendidas, assim, "a organização dos elementos da página atua, sobretudo, no sentido de informar, e não apenas de 'embelezar"' (GRUSZYNSKI, 2010, p. 15), 


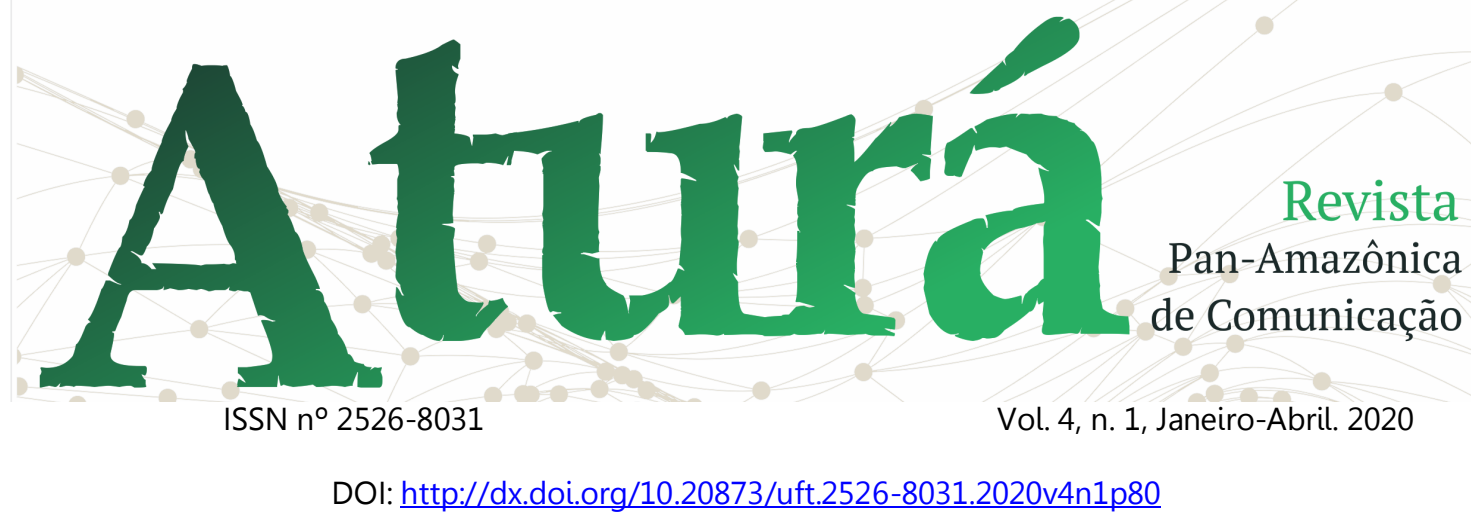

papel restritivo que comumente é atribuído ao design.

Diferente do jornal de papel e devido à materialidade dos suportes digitais, desaparecem os critérios imediatos, visíveis e materiais que permitem distinguir os textos, visto que "todos os textos, sejam eles quais forem, são entregues à leitura em um mesmo suporte (a tela do computador) e nas mesmas formas (geralmente as que são decididas pelo leitor". (CHARTIER, 2002, p. 109). Assim, não é possível, à primeira vista, identificar o tipo de publicação que está sendo acessada pela tela de um computador de mesa, o primeiro suporte que possibilita o acesso ao jornal na forma digital.

O texto nos suportes digitais "tal como conhecemos, é um texto móvel, maleável, aberto." (CHARTIER, 2002, p. 25). Assim, há uma mudança da fixidez do papel para a fluidez dos suportes digitais (FURTADO, 2006). Diferentemente do jornal impresso, que é composto por páginas e cadernos, no digital o jornal ganha uma outra textualidade.

a textualidade eletrônica permite desenvolver argumentações e demonstrações segundo uma lógica que já não é necessariamente linear nem dedutiva, tal como dá a entender a inscrição de um texto sobre uma página, mas que pode ser aberta, clara e racional graças à multiplicação dos vínculos hipertextuais. (CHARTIER, 2002, p. 24).

Desse modo, no que se refere ao espaço informacional do jornal, com o uso e a apropriação dos suportes digitais para a publicação de conteúdos pelos veículos jornalísticos, o conjunto de marcas que integram a área espacial dos jornais é levado para esses suportes, onde passam por reconfigurações. O nome do jornal, por exemplo, "[...] assume outros posicionamentos espaciais, configurações gráficas e funcionais (é um link, por exemplo, para a 'página' inicial)." (GRUSZYNSKI, 2012, p. 91). Já as editorias dos periódicos são apresentadas em menus com links que redirecionam o usuário para outras páginas do website.

O design gráfico pode ser capaz de comunicar, seja no impresso ou no digital, por meio da organização dos elementos que compõem a página, seja pela escolha das cores ou pela disposição das notícias. 


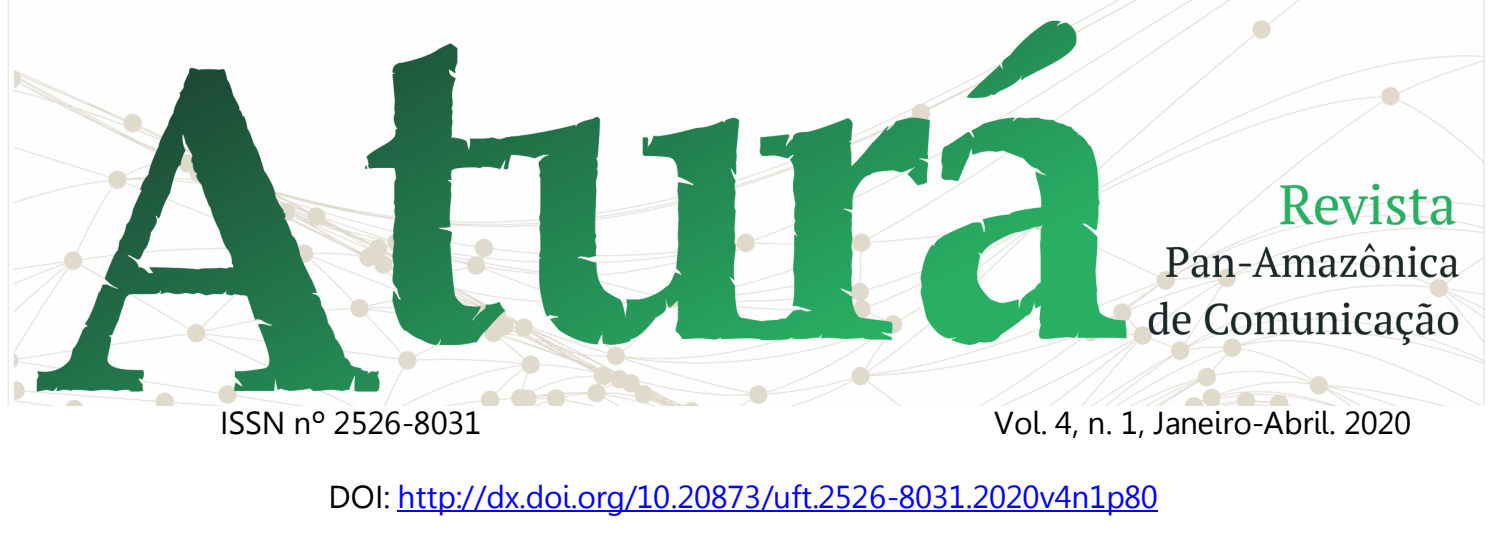

Segundo Bekesas (2006), a diagramação das notícias pode determinar o assunto estado potente, dependente desse interpretante para realizar-se (BEKESAS, 2006, p.11). com mais destaque, a fim de provocar o interesse e a apreensão das informações pelo leitor, especialmente diante da capa, a qual apresenta, atualiza e agenda os principais assuntos do dia. $\mathrm{O}$ autor destaca também a importância dos espaços em branco, pois o uso do fundo branco e maior espaçamento vertical e horizontal para não poluir a página com muita informação, sugere a noção de clareza do produto. Nesse sentido, o espaço, antes considerado "vazio" foi valorizado na composição da página, a fim de proporcionar destaques ao conteúdo jornalístico.

A capa de um jornal impresso, assim como a página inicial de um portal de notícias, segundo Bekesas (2006), pode apresentar seus traços, os caminhos para a compreensão da página e a sua estrutura, a partir da utilização do scanning.

É no scanning da página que a descoberta da notícia se fará, não somente como informação diagramada em ritmos propostos de leitura, de cima para baixo, da esquerda para a direita ou buscando as diagonais, mas também como a apreensão e atualização de algo em

A página do portal proporciona uma navegabilidade pela informação por meio da barra de rolagem e necessita de um suporte técnico para permitir o acesso do usuário, tendo em vista a necessidade de uma fonte de energia, como um computador pessoal ou celular, por exemplo. Enquanto o jornal, por ter o papel como suporte - leitura tátil -, pode ser deslocado de um lugar para o outro, dobrado ou rasgado, o que proporciona outro tipo de experiência ao leitor, além de não dependerem da instalação de programas ou energia para garantir o acesso (SOUSA, 2018).

Nesse sentido, Silva et. al (2018) apontam três categorias de elementos que compõem o design jornalístico multiplataforma em jornais impressos e digitais. São eles:

a) elementos tradicionais: referentes a padrões identificados no impresso (a manchete com texto com fonte maior e em negrito e a imagem em destaque); b) elementos híbridos: relativos à mistura de 


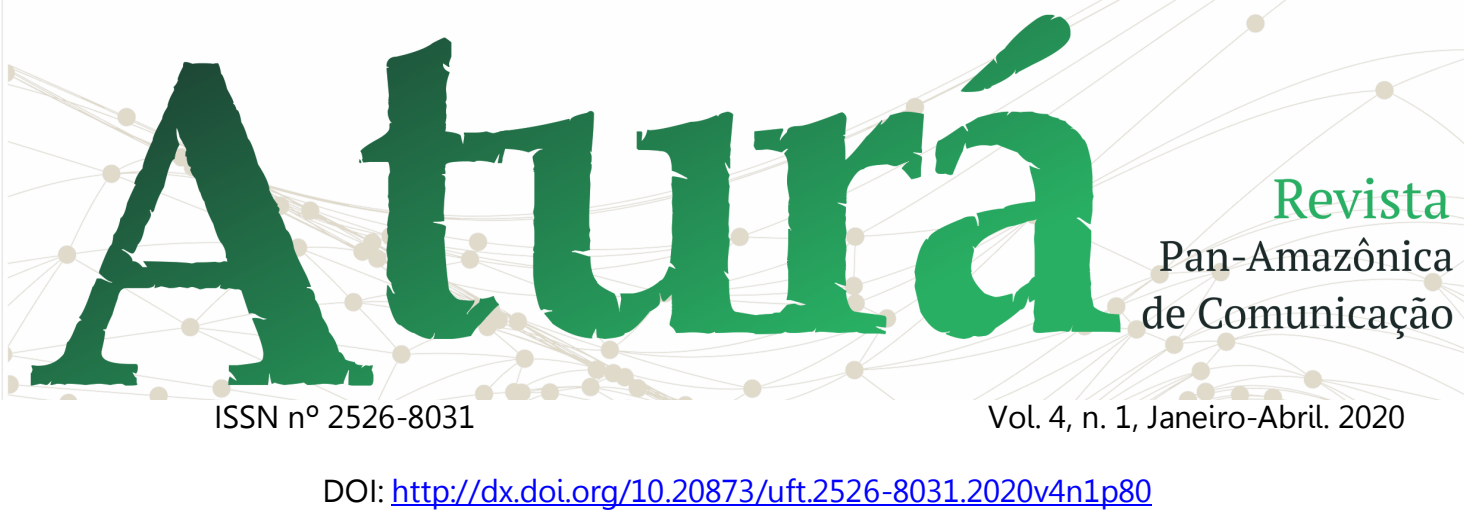

elementos do impresso e do digital (as chamadas com adição de multimídia e hiperlinks, além das informações personalizados como a previsão do tempo); c) elementos exclusivos: alusivos aqueles que são próprios do ambiente digital (os produtos em áudio ou em audiovisual, o menu com as editorias, os convites para interação com os sites de redes sociais).

A partir desta breve caracterização e diferenciação dos produtos jornalísticos impressos e digitais, nos dedicaremos a analisar as capas do jornal impresso 0 Liberal e do portal OLiberal.com.

Análise das capas de $\mathrm{O}$ Liberal: impresso e online

Esta pesquisa tem caráter exploratório (GIL, 1999), uma vez que visa proporcionar uma visão geral e um aprofundamento sobre um determinado fato: as características das capas (impressa e digital) de $O$ Liberal, com enfoque na apresentação visual. A abordagem utilizada na análise é a qualitativa que é tipicamente intencional e valoriza um estudo mais aprofundado da natureza dos fenômenos, sem se fundamentar em instrumentos estatísticos para compor o trabalho (análise quantitativa). Os estudos baseados nesse tipo de abordagem "podem descrever a complexidade de determinado problema, analisar a interação de certas variáveis, compreender e classificar processos dinâmicos vividos por grupos sociais" (RICHARDSON, 1999, p. 80). Desse modo, os procedimentos metodológicos utilizados foram: pesquisa bibliográfica, coleta de dados e análise.

Partimos do entendimento de que em um cenário de convergência jornalística (KOLODZY, 2006, 2009; SALAVERRÍA; AVILÉS; MASIP, 2010), o jornal "passa a existir além do suporte/plataforma papel, tornando-se um produto multiplataforma" (SOUSA, 2018, p. 182). Nesse sentido, o Grupo O Liberal é uma marca que possui produtos jornalísticos nas mais diversas plataformas (impresso, rádio, televisão, internet portal, sites de redes sociais, aplicativos). A análise será realizada a partir da observação das capas do jornal impresso 


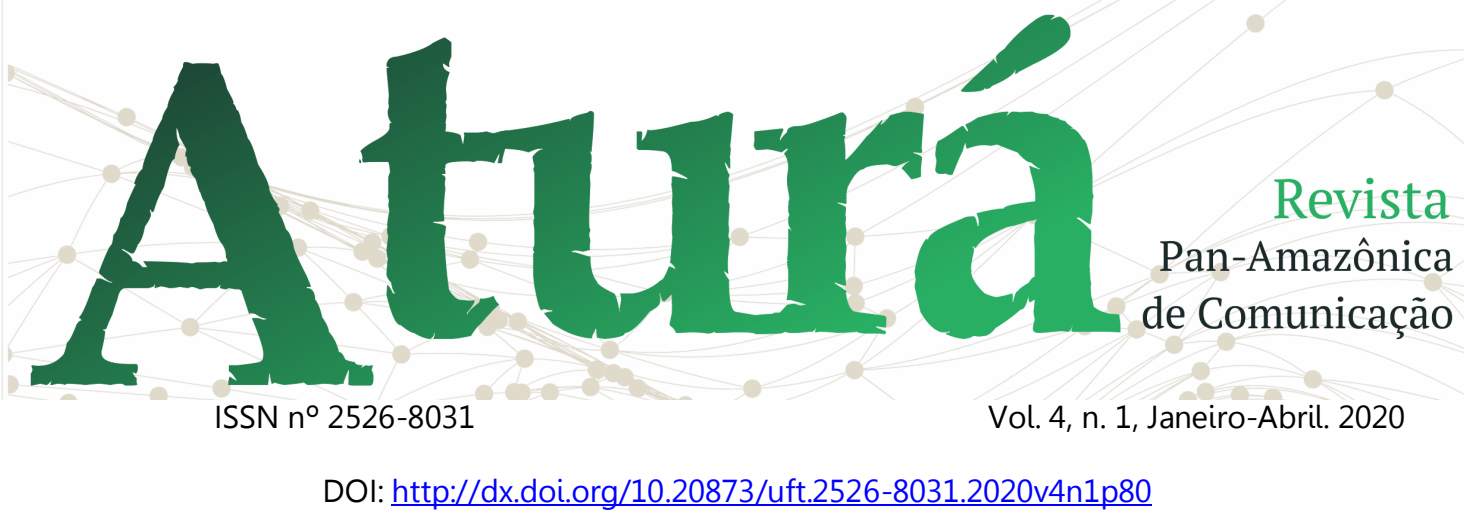

O Liberal e do portal OLiberal.com do dia três de julho de 2019 (ver Figuras 1 e 2), com base nas seguintes categorias: nome do jornal, diagramação, editorias, manchetes, disposição das notícias, imagens estáticas e em movimento, cores, tipografia, links e publicidade. É importante destacar que essas categorias não são isoladas.

Figura 1 - Capa do jornal impresso O Liberal do dia 03/07/19.

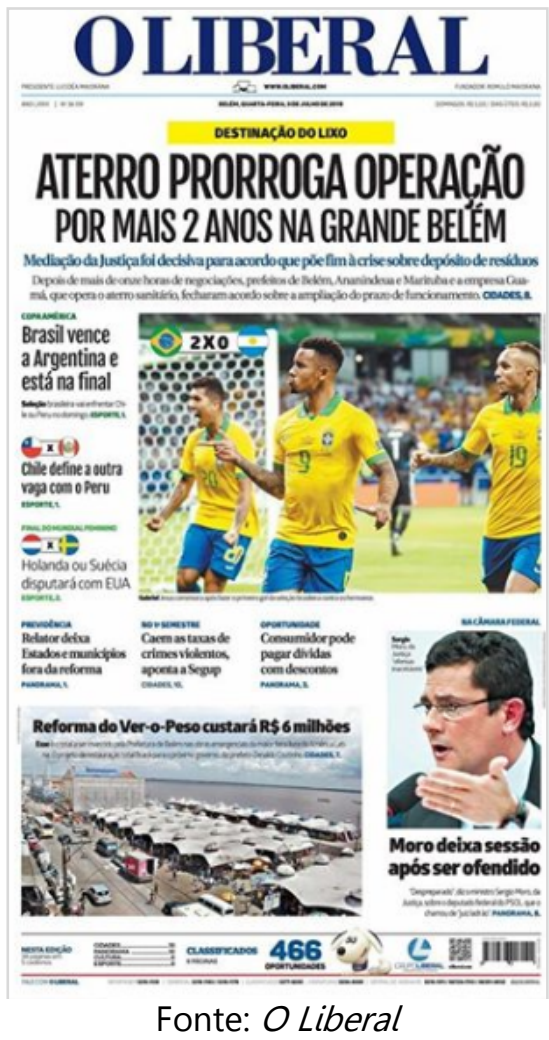

Figura 2 - Página inicial do portal OLiberal.com do dia 03/07/2019, às 09 horas.

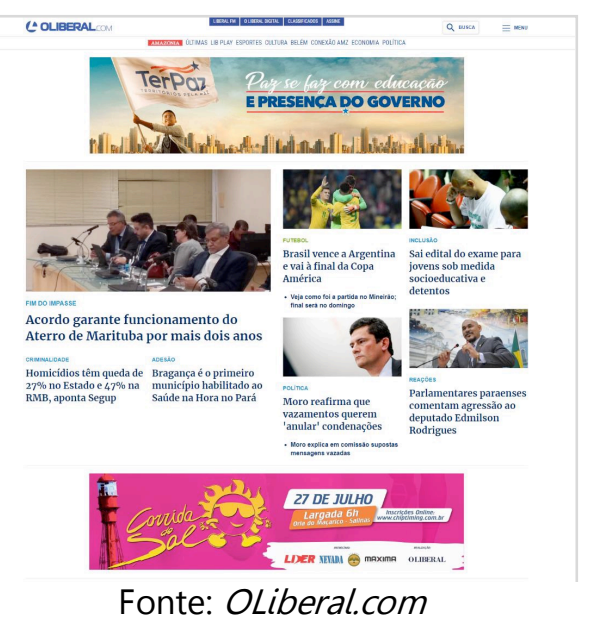

\section{Nome do jornal}

Embora os dois produtos tragam o nome "O Liberal" e a cor azul, observamos que não é o mesmo logotipo. No impresso, o logotipo traz a palavra "O Liberal" em letras com fontes com serifas (indicadas para leitura em papel) e em azul escuro (ver Figura 3). Já no digital, o logotipo apresenta a palavra "OLiberal.com" em letras com fontes sem serifas (recomendadas para leitura em tela) e em azul claro (ver figura 4). Há também um símbolo que acompanha o logotipo. De modo que, embora os dois logotipos tenham certa semelhança, os dois produtos em análise não apresentam uma única identidade visual. 


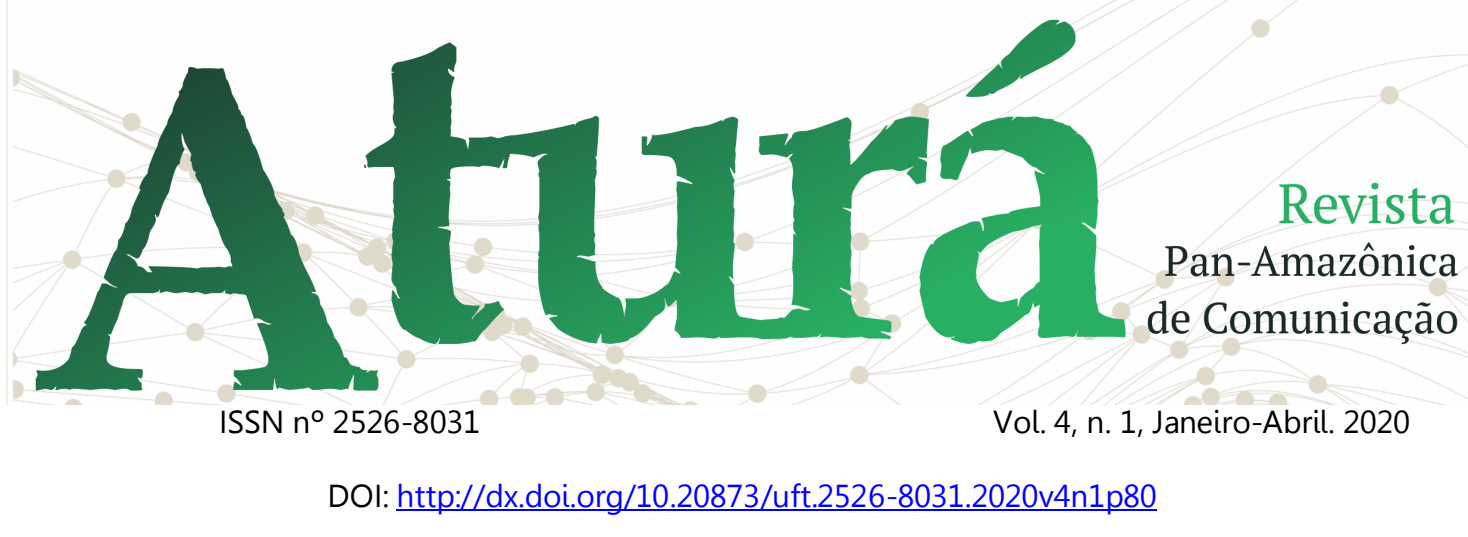

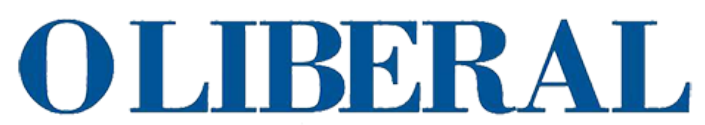

Fonte: O Liberal

Figura 4 - Logo do portal OLiberal.com.

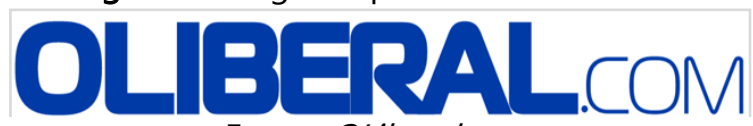

Fonte: OLiberal.com
Figura 3 - Logo do jornal impresso O Liberal.

estática, com elementos divididos em colunas e caixas.

Ambos utilizam elementos verticais e horizontais com o objetivo de criar uma página mais atraente. Entretanto, a capa do impresso tende a utilizar a verticalização de elementos, enquanto a capa do portal se aproxima dos elementos horizontais.

\section{Editorias}

A partir da diagramação das diagramação mais assimétrica em comparação ao jornal digital. A estrutura das colunas do impresso pode ser modificada de acordo com o tamanho das fotografias, tabelas ou charges utilizadas e com a disposição das manchetes noticiosas (exceto a principal que, em geral, ocupa a posição superior centralizada). O portal, por sua vez, apresenta estrutura mais simétrica, com disposição fechada dos blocos que compõem a página que são atualizados dentro de espaços sem muita alteração e apresentam uma composição mais as, a qual leva em consideração o movimento da retina dos leitores e usuários a fim de posicionar as notícias em cada espaço, percebemos o uso de cores específicas para cada editoria. É importante destacar, contudo, que se no impresso as editorias são divididas por cadernos, no digital, elas são divididas por menu.

Na capa do impresso, também se identificam as editorias em letras coloridas após cada manchete (coincidentes com a cor definida para cada caderno: Esporte, Cultura, Cidades). No caso da Figura 1, 


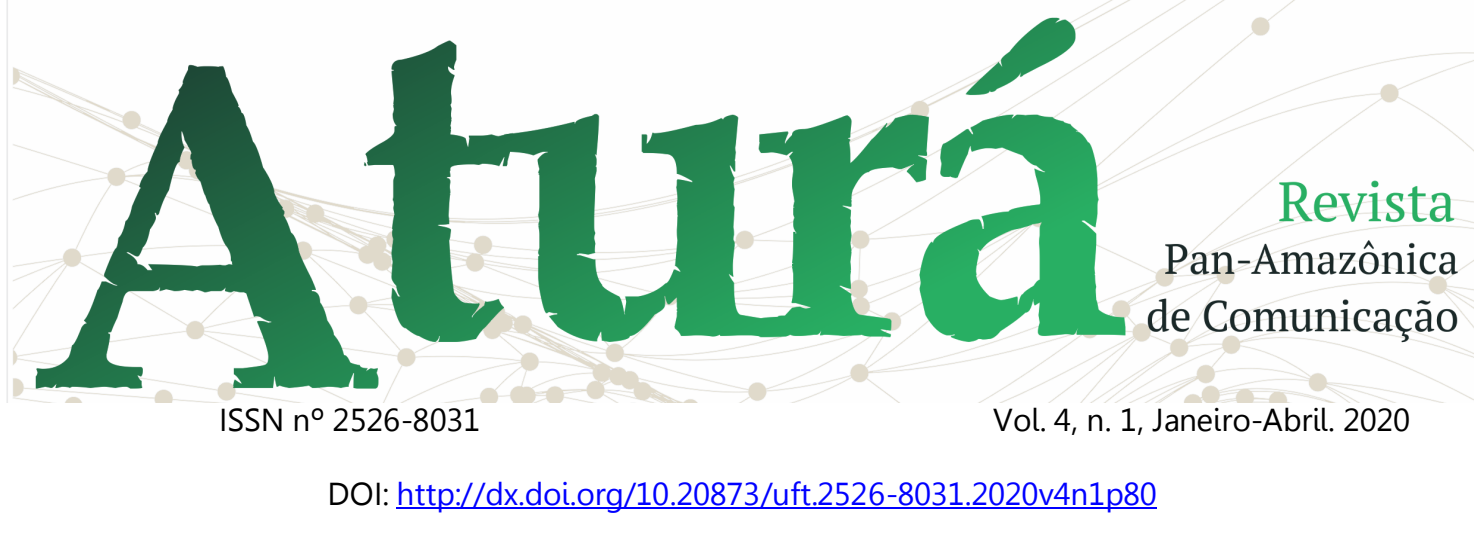

percebemos o uso da cor verde nas notícias relacionadas a esporte e a indicação do caderno (editoria) e da página onde encontra-se a matéria da chamada. Na capa do digital, as editorias podem ser identificadas tanto no menu (localizado do lado direito do topo) quanto nas linhas coloridas que organizam as notícias por temáticas. No caso da Figura 2, observamos o uso de linhas vermelhas, verdes e alaranjadas para conteúdos relacionados à Amazônia, Esporte e Cultura, respectivamente.

\section{Manchetes}

Verificamos que, no impresso, a manchete principal apresenta-se de duas formas: ou em negrito e em proporção maior ou com uma imagem que chame a atenção do leitor. É importante salientarmos que a posição da imagem varia entre centro, direita e esquerda (ver Figura 1). Entretanto, sempre é apresentada em maiores proporções e na parte superior da página. Já a principal matéria do dia no portal é posicionada do lado esquerdo superior da página e em maiores proporções, tanto de fotografia como de tipografia, se comparado às outras matérias do dia (ver Figura 2).

Observamos, contudo, que as notícias não são apresentadas em sua totalidade nesses espaços. Há um processo de seleção das notícias, de acordo com os critérios de noticiabilidade e interesse do veículo. Em ambas as capas, as notícias são publicadas com informações restritas organizadas em um breve lide ou somente pela manchete aliada ao índice que encaminha o leitor para o interior do jornal (impresso ou digital).

Aqui é importante destacar outro aspecto que precisa ser considerado em relação às manchetes: o deadline. Se no jornal impresso há a hora do fechamento do jornal para enviar à impressão, no digital esse deadline não existe. Assim, no impresso a manchete dura o dia inteiro, diferente do digital que pode ter várias manchetes por dia dependendo dos acontecimentos.

\section{Disposição das notícias}




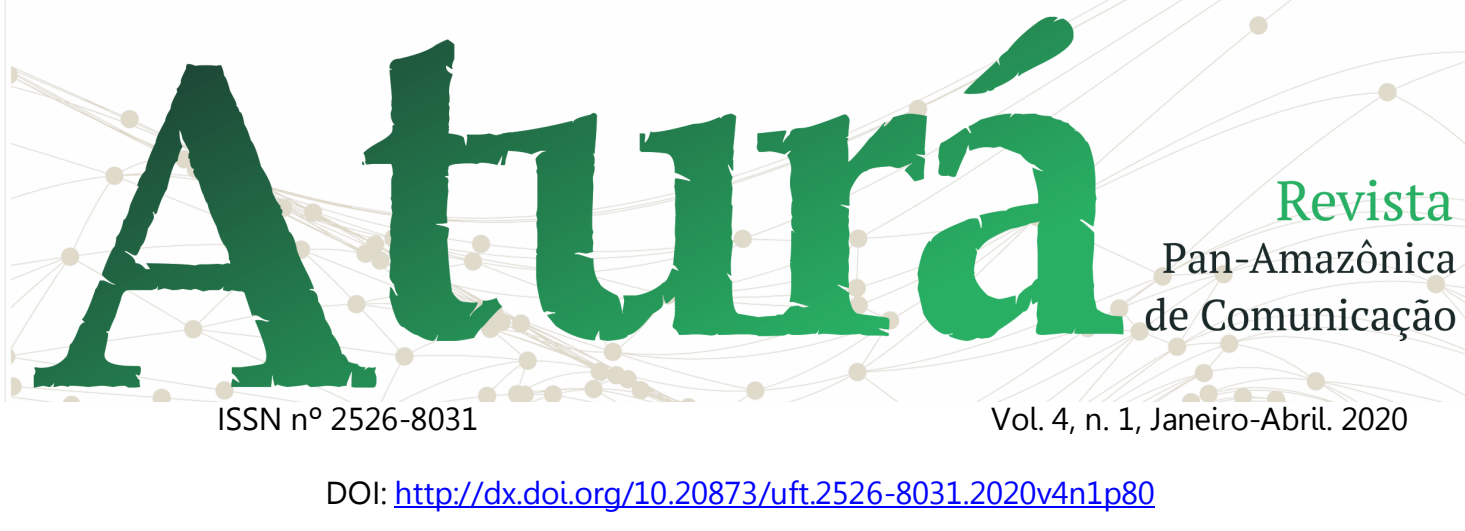

Cada meio possui uma estrutura e uma ordem de apresentação das notícias. O jornal impresso apresenta uma manchete principal em destaque que pode ser ou não acompanhada do assunto - identificado em amarelo acima da manchete principal (ver Figura 1), mas, em geral, seguida de um sutiã com informações adicionais sobre a notícia, além das fotografias, charges, tabelas, gráficos e espaço destinado para as manchetes e subtítulos com menor proporção que completam a composição da página.

Já o portal identifica os destaques principais do dia (sem editorias prédefinidas) na parte superior da página. Ao utilizar a barra de rolagem, é possível identificar, normalmente, três ou quatro manchetes acompanhadas de uma imagem estática em cada editoria ao longo da página inicial (ver Figura 2). A hierarquia dos conteúdos é identificada por meio da diversificação de tamanhos de fotografia e de letra, além dos aspectos referentes ao design gráfico, como a escolha da posição do principal elemento.

\section{Imagens estáticas e em movimento}

Percebemos que as imagens estáticas, sobretudo fotografias, são muito utilizadas na estrutura dos dois modelos de capa (impresso e digital), ocupando, geralmente, a maior proporção do espaço destinado aos conteúdos na página no jornal impresso, assim como na página inicial do portal, na qual a maioria das chamadas possuem uma fotografia acima da manchete. Essas imagens, além de transmitirem informação em complementaridade com os textos jornalísticos, constituem uma experiência estética ligada às emoções, sensações e percepções, dos leitores tanto do impresso quanto do digital.

Não encontramos imagens em movimento na capa do portal OLiberal.com.

\section{Cores}

Percebemos que tanto $\mathrm{o}$ jornal impresso quanto o digital apresentam a predominância das cores azul e preto. Contudo, no impresso é usado também o 


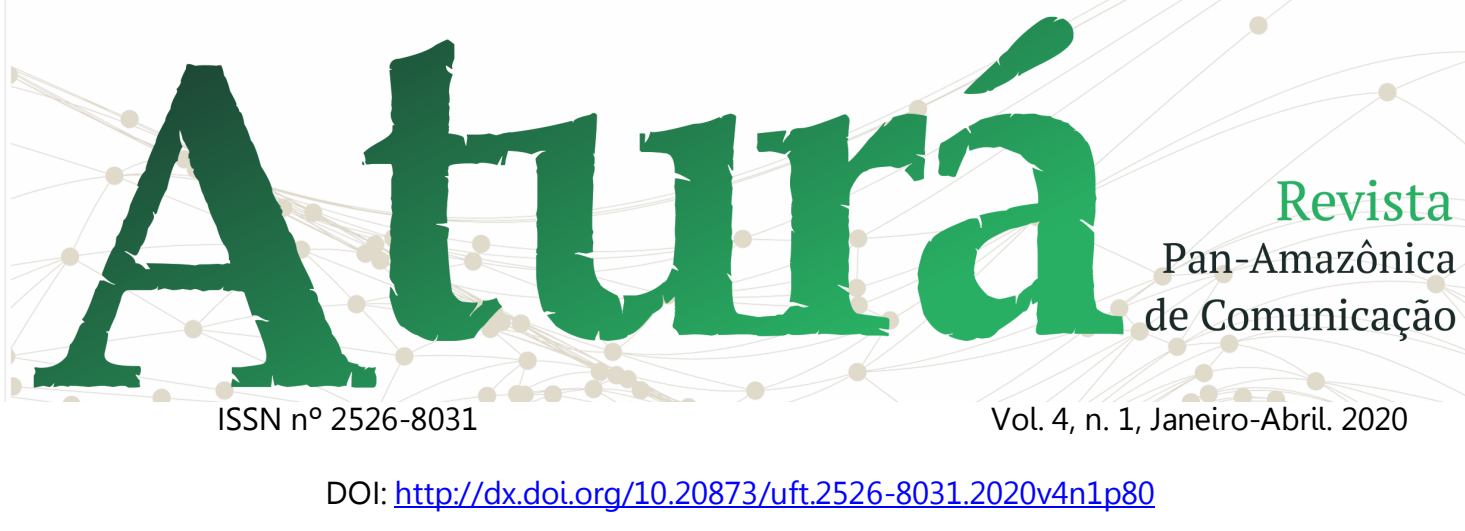

amarelo - nas edições com o assunto em destaque acima da manchete principal (ver Figura 1). Nos dois casos, são usadas as cores vermelho, verde e alaranjado, em menor proporção, para relacionar as manchetes às suas respectivas editorias.

A mistura entre cores frias (azul) e quentes/fortes (amarelo, vermelho, verde e alaranjado) envolve o conjunto de informações que possuem capacidade de provocar a atenção dos leitores, além de poder sugerir a ideia de modernidade, serenidade e credibilidade do veículo. É importante destacarmos que, nas duas capas, observamos o uso de espaços em branco como recurso para dar mais clareza às páginas.

\section{Tipografia}

A diferença de tipografia já é observada entre os dois produtos desde $\mathrm{o}$ logotipo, como explicado anteriormente. $\mathrm{Na}$ edição impressa são utilizadas diferentes opções de tipografia, além das ferramentas negrito, maiúscula e minúscula e variação de tamanhos das letras. Já na edição digital há uma unidade visual, tendo em vista a uniformização desse quesito pelo próprio sistema gerador de conteúdo.

\section{Links}

Se no digital as chamadas possuem links que direcionam o leitor para a página com o conteúdo noticioso, no impresso as indicações de páginas e cadernos atuam como links da página inicial do portal (como "leia mais" ou "acompanhe"), os quais indicam que há mais informação disponível e possibilita a continuidade da leitura. Contudo, os jornais impressos possuem um espaço limitado, diferente do digital que é ilimitado e pode contar com inúmeros hiperlinks, redirecionando os leitores para outros conteúdos. Assim, os modos de leitura dos dois objetos em análise também divergem e promovem experiências diferentes.

É importante destacarmos também, que diferente do jornal impresso, no topo do portal há links que direcionam os leitores para os sites de redes sociais (WhatsApp, YouTube, Twitter, Facebook e Instagram) do jornal, possibilitando o 


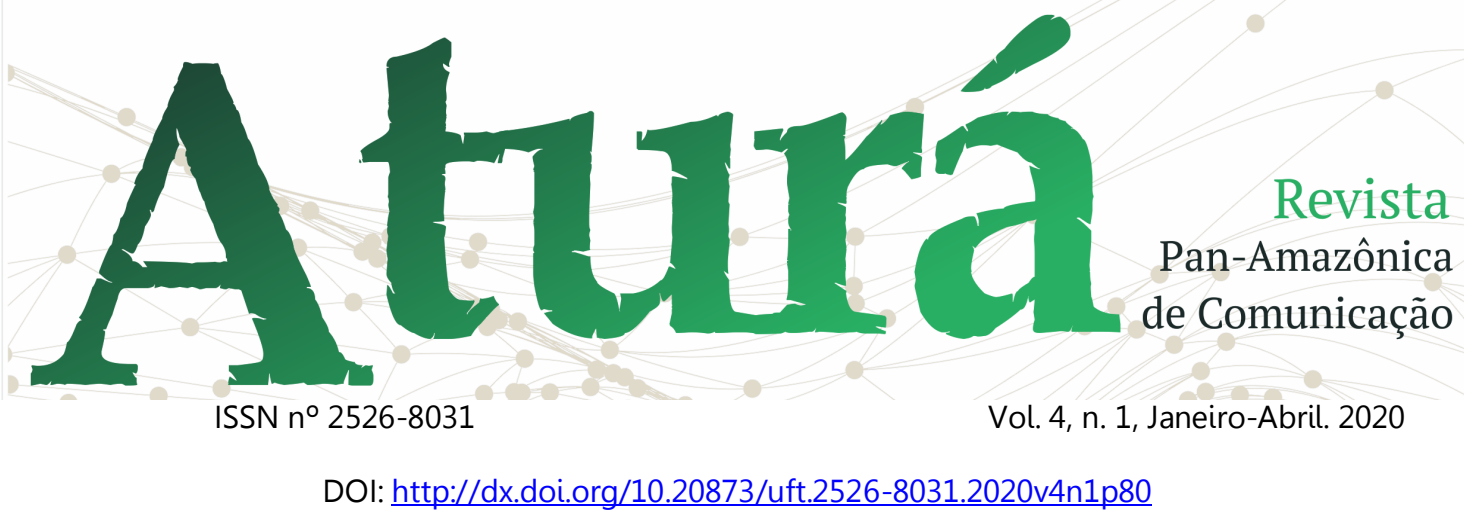

acesso ao jornal por meio de outras plataformas digitais do grupo $\mathrm{O}$ Liberal.

\section{Publicidade}

O jornal impresso, em geral, não faz uso de publicidade em sua capa. No entanto, percebemos que ao abrir a página inicial do portal OLiberal.com, mesmo antes da apresentação das principais notícias do dia, há a disponibilização de propagandas que se alternam (vinculadas às empresas privadas e ao governo do Estado), além da disponibilização de outros anúncios entre os destaques das editorias. Nesse sentido, com base nas capas dos meios estudados, percebemos que a uma diferença entre $o$ uso da publicidade nos dos produtos em análise.

\section{Considerações finais}

Este artigo dedicou-se a analisar as características pertinentes à capa do jornal O Liberal no impresso e no digital, com foco na apresentação visual. De caráter qualitativo, o estudo exploratório combinou as seguintes técnicas: pesquisa bibliográfica, coleta de dados e análise. A análise foi realizada a partir da edição do dia três de julho de 2019 do jornal impresso $O$ Liberal e do portal OLiberal.com, com base nas seguintes categorias: nome do jornal, diagramação, editorias, manchetes, disposição das notícias, imagens estáticas e em movimento, cores, tipografia, links e publicidade.

Com a análise foi possível concluir que embora a marca $\mathrm{O}$ Liberal que possui valor ideológico e econômico (GRUSZYNSKI, 2016) tenha se tornado um produto multiplataforma (SOUSA, 2018), ampliando e redimensionando os contratos de comunicação estabelecidos com o público leitor (CHARAUDEAU, 2007; BELOCHIO, 2012; GRUSZYNSKI; LINDEMANN; OLIVEIRA, 2014), como uma estratégia da convergência jornalística (KOLODZY, 2006, 2009; SALAVERRÍA; AVILÉS; MASIP, 2010), as capas dos dois produtos mostram que não há uma identidade visual que realmente interligue as edições impressa e digital do grupo $O$ Liberal, embora haja alguma relação entre 


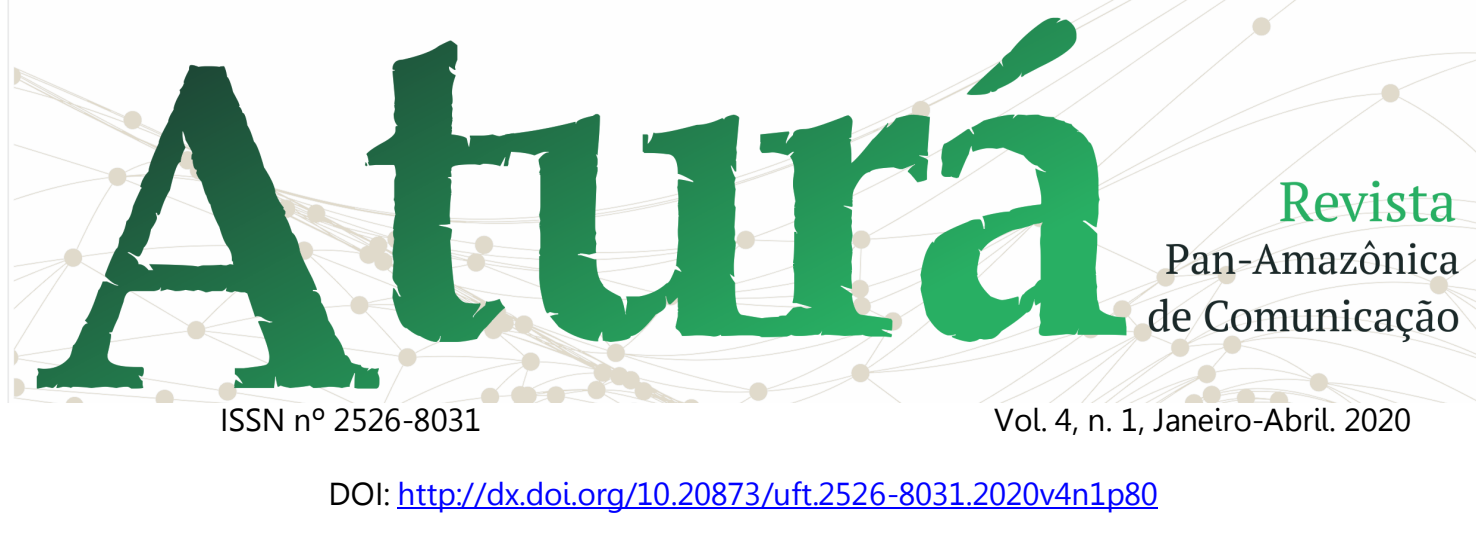

as cores utilizadas. Desse modo, a relação entre os elementos que compõem as capas do jornal impresso e digital possuem potencial de transmitir diferentes significações e experiências para um indivíduo, experiências essas que variam de acordo com os conhecimentos individuais, interesses, habilidades e interpretação de cada um.

Nesse sentido, ressaltamos que 0 portal OLiberal.com não é apenas a digitalização do jornal impresso, mas sim uma produção específica para o veículo. Há o diálogo entre as duas - percebemos como uma consequência da integração das redações realizada pelo Grupo em 2018 - mas existe uma independência visual entre elas, especialmente pelo nome do jornal (logotipo) e pelas características da hipertextualidade, interatividade e instantaneidade proporcionadas pela internet. Consideramos, entretanto, que diante de inúmeras possibilidades de recursos proporcionados pelo ambiente digital, o portal faz uso restrito de tais potencialidades.

\section{Referências}

BANDEIRA, Ana Rosa et al. Estratégias de pesquisa em jornalismo e design editorial. In. ROSÁRIO, Nísia Martins do; SILVA, Alexandre Rocha da. (Orgs.). Pesquisa, comunicação, informação. Porto Alegre: Sulina, 2016.

BEKESAS, Wilson Roberto. A interface da notícia nos meios impresso e digital: $O$ tratamento da notícia nas primeiras páginas dos jornais impressos e portais na Internet. Dissertação (Mestrado em Comunicação e Semiótica) - Pontifícia Universidade Católica de São Paulo, São Paulo, 2006. 92p.

BELOCHIO, Vivian de Carvalho. Jornalismo em contexto de convergência: implicações da distribuição multiplataforma na ampliação dos contratos de comunicação dos dispositivos de Zero Hora. 2012. Tese (Doutorado em Comunicação e Informação). Programa de Pós-Graduação em Comunicação e Informação, Universidade Federal do Rio Grande do Sul, Porto Alegre, 2012.

CANAVILHAS, João (Org.). WebJornalismo: 7 Caraterísticas que marcam a diferença. Covilhã: Livros LabCOM, 2014.

CASTRO, Avelina Oliveira de; SEIXAS, Netília Silva dos Anjos. História, discursos e relações de poder nas páginas de 0 Liberal. In. Anais do 9o Encontro Nacional de História da Mídia - ALCAR, 2013, Ouro Preto - MG. Anais... Ouro Preto: 2013.

CHARAUDEAU, Patrick. Discurso das mídias. São Paulo: Contexto, 2007. 


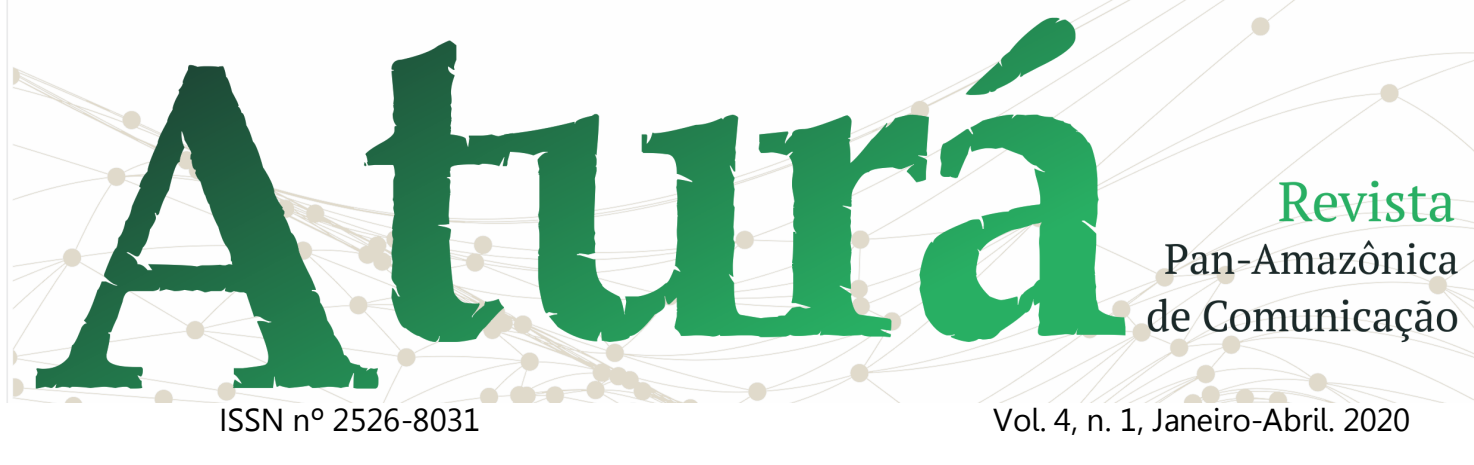

DOI: http://dx.doi.org/10.20873/uft.2526-8031.2020v4n1p80

CHARTIER, Roger. Os desafios da escrita. São Paulo: Editora UNESP, 2002.

FURTADO, José Afonso. O papel e o pixel. Do impresso ao digital: continuidades e transformações. Florianópolis: Escritório do Livro, 2006.

GIL, Antônio Carlos. Métodos e técnicas de pesquisa social. São Paulo: Atlas, 1999.

GRUSZYNSKI, Ana Cláudia. Jornal Impresso: Produto Editorial Gráfico em Transformação. Anais... Intercom. 2010. XXXIII Congresso Brasileiro de Ciências da Comunicação - Caxias do Sul, RS - 2 a 6 de setembro de 2010.

GRUSZYNSKI, Ana Cláudia. O papel do design no estabelecimento de contratos de leitura de jornais impressos: um estudo sobre a reforma gráfica de 2010 da Folha de S. Paulo (Brasil). Estudos em Comunicação, no 12, 2012.

GRUSZYNSKI, Ana Cláudia. Dispositivos de leitura no cenário de convergência de mídias. In. RÖSING, Tania; ZILBERMAN, Regina (Orgs.). Leitura: história e ensino. Porto Alegre: Edelbra, 2016. p. 169-187.

GRUSZYNSKI, Ana; LINDEMANN, Cristiane; OLIVEIRA, Cássia de. Virando-se por leitores: a reforma editorial e gráfica do jornal Zero Hora no cenário de convergência (2014). In. Anais do XXXVII Congresso Brasileiro de Ciências da Comunicação - INTERCOM, 2014, Foz do Iguaçu - PR. Anais... Foz do Iguaçu: 2014.
GRUSZYNSKI, Ana; SANSEVERINO, Gabriela. Processos de produção e design editorial multiplataforma: um olhar sobre o jornal Zero Hora. Lumina, v. 8, n. 2, 2014. p. 1-23.

KOLODZY, Janet. Convergence journalism - writing and reporting across the News media. Oxford (UK): Rowman \& Littlefield publishers, 2006.

KOLODZY, Janet. Convergence Explained. In: GRANT, August. E.; WILKINSON, Jeffrey. S. (Orgs.). Understanding Media Convergence. New York: Oxford University Press, 2009. p.31-51.

MOUILLAUD, Maurice. Da forma ao sentido. In. MOUILLAUD, Maurice; PORTO, Sérgio Dayrell (Orgs.). O jornal: da forma ao sentido. Brasília: Paralelo 15, 1997.

PARK, Robert. A história natural do jornal. In: BERGER, Christa; MAROCCO, Beatriz (orgs.). A era glacial do jornalismo: teorias sociais da imprensa. Volume 2. Porto Alegre: Sulina, 2008.

RICHARDSON, Roberto Jarry. Pesquisa social: métodos e técnicas. São Paulo: Atlas, 1999.

SALAVERRÍA ALIAGA, Ramón; GARCIA AVILÉS, José Alberto; MASIP MASIP, Pere Masip. Concepto de convergencia periodística. In: LÓPEZ GARCIA, Xosé; PEREIRA FARIÑA, Xosé (Orgs.) Convergência Digital: Reconfiguración de los Medios de Comunicación en España. Santiago de Compostela: Universidade, 


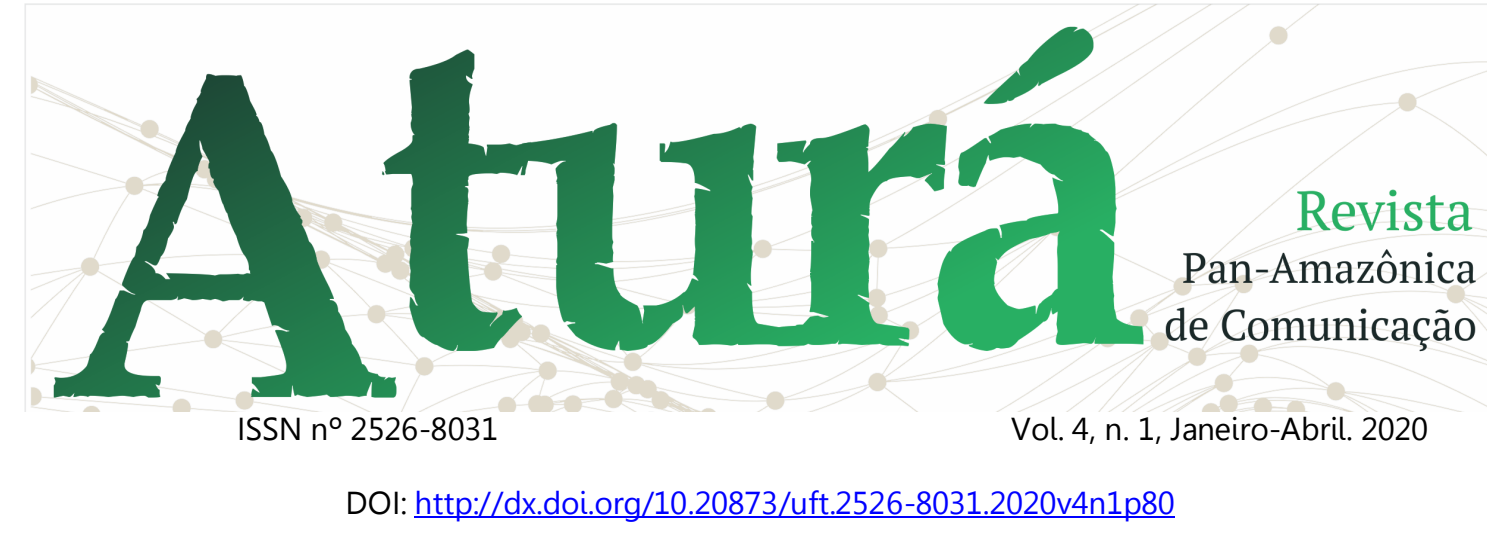

Servizo de Publicacións e Intercambio Científico, 2010. p.41-64.

SEIXAS, L. VALORES NOTÍCIA: uma proposta de análise. Revista Observatório, v. 4, n. 4, p. 334-366, 29 jun. 2018.

SILVA, Gislene. A ENGRENAGEM DA NOTICIABILIDADE NO MEIO DO REDEMOINHO. Revista Observatório, v. 4, n. 4, p. 308-333, 29 jun. 2018.

SILVA, Alexia. et al. Design jornalístico multiplataforma em Zero Hora impresso e webjornal. $O$ ciberjornalismo em OLIBERAL.com. In. Anais do 100 Salão Internacional de Ensino, Pesquisa e Extensão da UNIPAMPA, 2018, Bagé - RS. Anais... Bagé: 2018.

SOUSA, Maíra de Cássia Evangelista de. Jornalismo digital no Pará: análise do Portal ORM, do Portal Cultura e do Diário do Pará. Trabalho de Conclusão de Curso (Graduação em Comunicação Social Jornalismo). Faculdade de Comunicação, Universidade Federal do Pará, Belém, 2008.

SOUSA, Maíra de Cássia Evangelista de. NOTÍCIAS NO PULSO: Uma análise de aplicativos jornalísticos em relógios inteligentes. Revista Observatório, v. 3, n. 1, p. 457-479, 30 mar. 2017.

SOUSA, Maíra de Cássia Evangelista de. Jornal e mobilidade: reconfigurações do impresso ao multiplataforma. 2018. Tese (Doutorado em Comunicação e Informação). Programa de Pós-Graduação em Comunicação e Informação,
Universidade Federal do Rio Grande do Sul, Porto Alegre, 2018.

SOUSA, Maíra de Cássia Evangelista de; ABREU, Giovanna Figueiredo de. O ciberjornalismo em OLIBERAL.com. In. Anais do 17o Encontro Nacional de Pesquisadores em Jornalismo - SBPJOR, 2019, Goiânia - GO. Anais... Goiânia: 2019. 